\title{
2021 Handbook of Florida Water Regulation: Florida Department of Health ${ }^{1}$
}

\author{
Michael T. Olexa, Tatiana Borisova, and Jana Caracciolo²
}

\section{Preface}

This handbook is designed to provide an accurate, current, and authoritative summary of the principal federal and state (Florida) laws that directly or indirectly relate to agriculture. This handbook provides a basic overview of the many rights and responsibilities that farmers and farmland owners have under both federal and state laws as well as the appropriate contact information to obtain more detailed information. However, the reader should be aware that because the laws, administrative rulings, and court decisions on which this handbook is based are subject to constant revision, portions of this publication could become outdated at any time. Several details of cited laws are also left out due to space limitations. This handbook is provided as an educational text for those interested in water use and water resource issues in Florida.

This handbook is distributed with the understanding that the authors are not engaged in rendering legal or other professional advice, and the information contained herein should not be regarded as a substitute for professional advice. This handbook is not all inclusive in providing information to achieve compliance with the federal and state laws and regulations governing water protection. For these reasons, the use of these materials by any person constitutes an agreement to hold harmless the authors, the UF/IFAS Center for Agricultural and Natural Resource Law, and UF/IFAS Extension for any liability claims, damages, or expenses that may be incurred by any person as a result of reference to or reliance on the information contained in this handbook. Note: UF/IFAS is the acronym for University of Florida, Institute of Food and Agricultural Sciences.

\section{FDOH Overview}

The Florida Department of Health (FDOH) is largely responsible for implementing procedures to promote and protect public health and safety. Farmers must consider FDOH regulations when they are involved in activities that might impact the quality of public drinking supplies. FDOH conducts well surveys and sampling for Florida Department of Environmental (FDEP) to protect, manage, and prioritize the cleanup of contaminated sites. FDOH also provides an alternate drinking source when the water exceeds the maximum contaminant level. For a list of the maximum contaminant levels for individual chemicals, visit http://www.floridahealth.gov/Environmental-Health/ drinking-water/_documents/hal-list.pdf.

Of particular concern to the agency is sewage pollution of Florida's groundwater. FDOH issues permits for construction or installation of septic tanks and other onsite sewage treatment and disposal systems. These permits include requirements for the following:

1. This document is FE597, one of a series of the Food and Resource Economics Department, UF/IFAS Extension. Original publication date October 1998. Revised June 2017 and April 2021. Visit the EDIS website at https://edis.ifas.ufl.edu for the currently supported version of this publication.

2. Michael T. Olexa, professor, Food and Resource Economics Department, and director, UF/IFAS Center for Agricultural and Natural Resource Law; Tatiana Borisova, associate professor, Food and Resource Economics Department; and Jana Caracciolo, student Levin College of Law; UF/IFAS Extension, Gainesville, FL 32611.

The Institute of Food and Agricultural Sciences (IFAS) is an Equal Opportunity Institution authorized to provide research, educational information and other services

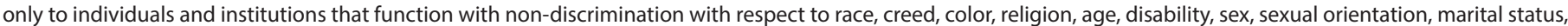

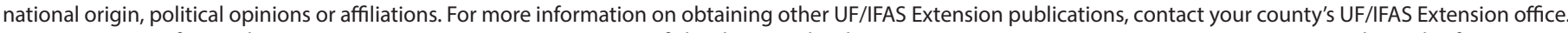
U.S. Department of Agriculture, UF/IFAS Extension Service, University of Florida, IFAS, Florida A \& M University Cooperative Extension Program, and Boards of County Commissioners Cooperating. Nick T. Place, dean for UF/IFAS Extension. 
- Distance and set-backs from wells and surface waters

- Soil conditions

- Estimated seasonal high water table

- Daily flow thresholds (see FE614, Onsite Sewage Treatment and Disposal)

Written permits issued through the local county health department branch of FDOH are required prior to constructing any onsite sewage treatment and disposal system. FDOH will penalize anyone who unlawfully deposes filth or polluting substances.

More information can be found at the $\mathrm{FDOH}$ website (http://www.doh.state.fl.us/).

\section{Acknowledgments}

The authors are indebted to the personnel of both state and federal agencies who provided their time and advice in the preparation of this handbook. We acknowledge Carol Fountain and Susan Gildersleeve at the University of Florida for their assistance in editing this handbook. We also acknowledge funding received for updating this publication from the James S. and Dorothy F. Wershow Agricultural Law Endowment. 